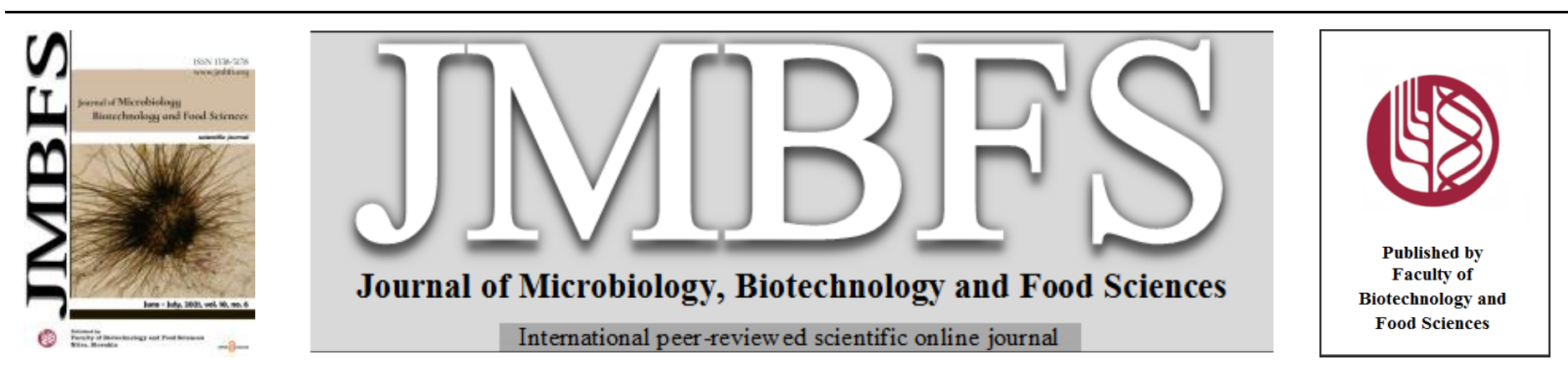

\title{
CHEMICAL COMPOSITION OF MUSCLE AFTER RED GRAPE POMACE APPLICATION IN THE NUTRITION OF BROILER CHICKENS
}

\section{Matej Čech ${ }^{1 *}$, Peter Haščík ${ }^{l}$, Adriana Pavelkovál , Juraj Čuboňn ${ }^{1}$, Ondřej Bučko ${ }^{2}$, Jana Tkáčovál, Miroslava Kačániová3 , Marek Bobkol, Ivan Imrich ${ }^{4}$, Kristián Š́r ${ }^{1}$}

Address(es): Ing. Matej Čech,

${ }^{1}$ Slovak University of Agriculture in Nitra, Faculty of Biotechnology and Food Science, Department of Technology and Quality of Animal Products, Tr. A. Hlinku 2, 94976 Nitra, Slovakia.

${ }^{2}$ Slovak University of Agriculture in Nitra, Faculty of Agrobiology and Food Resources, Department of Animal Husbandry, Tr. A. Hlinku 2, 94976 Nitra, Slovakia. ${ }^{3}$ Slovak University of Agriculture in Nitra, Faculty of Horticulture and Landscape Engineering, Department of Fruit Science, Viticulture and Enology, Tr. A. Hlinku 2, 94976 Nitra, Slovakia.

${ }^{4}$ Slovak University of Agriculture in Nitra, Faculty of Agrobiology and Food Resources, Department of Veterinary Sciences, Tr. A. Hlinku 2, 94976 Nitra, Slovakia.

*Corresponding author: matej.mcech@gmail.com

https://doi.org/10.15414/jmbfs.3726

\section{ARTICLE INFO}

Received 18. 9. 2020

Revised 23. 4. 2021

Accepted 7. 5. 2021

Published 1. 6. 2021

Regular article open $\partial_{\text {ACCESS }}$

\section{ABSTRACT}

The aim of this work was to evaluate basic chemical composition (\% of water, protein, fat and cholesterol) of breast and thigh muscle after supplementation with Alibernet red grape pomace (RGP) into diet of broiler chickens Ross 308. At the beginning, 200 one-day Ross 308 broiler chickens of mixed gender were randomly divided into 4 groups $(n=50)$. The control group (C) did not receive any additional supplementation. The feed of experimental group E1 was enriched with $1 \%$ RGP per $1 \mathrm{~kg}$ of feed mixture (FM), experimental group E2 with 2\% RGP per $1 \mathrm{~kg}$ of FM and experimental group E3 with 3\% RGP per $1 \mathrm{~kg}$ of FM. The FMs were produced without any antibiotics and coccidiostatics and the fattening period lasted for 42 days. Based on the results, we can state that the application of red grape pomace did not significantly affect the chemical composition of the breast muscle except of higher fat content $(\mathrm{P} \geq 0.05)$ in all experimental groups compared to control group $(\hat{O}$,, $)$. In the case of thigh muscle, we found significantly higher $(\mathrm{P} \leq 0.05)$ water content $\left({ }^{-1}\right)$ in control group $\left(71.26 \mathrm{~g} .100 \mathrm{~g} \mathrm{~g}^{-1}\right)$ compared to experimental groups E2 $\left(70.04 \mathrm{~g} .100 \mathrm{~g}^{-1}\right)$ and E3 $\left(69.51 \mathrm{~g}^{-100 ~ \mathrm{~g}^{-1}}\right)$. We also found significant differences $(\mathrm{P} \leq 0.05)$ in crude protein content $\left({ }^{\Uparrow}\right)$ between experimental group E3 $\left(21.91 \mathrm{~g}^{\left.-100 \mathrm{~g}^{-1}\right)}\right.$ compared to experimental groups E1 (21.63 g.100 g $\left.\mathrm{g}^{-1}\right)$ and E2 (21.59 g.100 g $\left.\mathrm{g}^{-1}\right)$. Overall, it seems like that supplementation with RGP in selected amounts did not have significant beneficial effect on chemical composition of chicken meat compared to control group.

Keywords: grape pomace, broiler chicken, meat, chemical composition

\section{INTRODUCTION}

Poultry meat is a very good source of proteins with high biological value and micronutrients, which is provided mainly by meat and eggs. Human body is more capable to absorb these nutrients compared to those of plant origin (Raza, Bashir and Tabassum, 2019). Poultry meat production in the world is about to reach 137 million tons in 2020 , what is $2.4 \%$ more than in 2019 or half the pace of growth recorded last year. Countries like China, the EU, UK, Brazil and Mexico are expected to rise their production, while in India, Thailand, Turkey and the USA production is currently falling. However, the positive outlook could turn negative if recent price drops and unavailability of workers in the sector linked to COVID-19 will continue (FAO, 2020). Poultry and its main products, meat and eggs, as well as products made from them are of a great importance to humans because they provide an excellent source of proteins, fats, essential amino acids, minerals, vitamins and other nutrients. Big advantage is that they are available world wide (Shaltout, 2019)

Chicken meat is sensory-neutral and thanks to its high tenderness is found to be used in miscellaneous meat products aimed at various consumers. Chicken meat is widely used in the world cuisines thanks to its undemanding preparation what is an advantage especially nowadays, because people have less time to prepare foods (Petracci et al., 2013). There are many religious and social restrictions for consuming red meats, mainly pork, what is not issue of chicken meat. Moreover, comparing with other meat types, it is one of the cheapest kinds (Haščík et al., 2018a). Chicken meat is known for its considerable protein content - average of $22 \%$ (Bobko et al., 2017). Chicken proteins are known also for their good digestibility (94\%) (Williams, 2007) and high AAS (0.92), compared to legumes (AAS value $=0.57-0.71)$ and wheat gluten only AAS $=0.25$ (Pereira and Vicente, 2013). Čuboň et al. (2013) describes basic chemical composition for breast and thigh muscle as follows: dry matter (\%) 25.8 and 26.0, respectively in breasts and 33.1 and 32.6, respectively in thighs; protein content $\left(\mathrm{g} .100 \mathrm{~g} \mathrm{~g}^{-1}\right) 22.9$

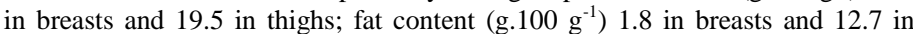
thighs and Cavani et al. (2009) add energy value (kcal) 104, resp. 115; cholesterol (mg) 62, resp. 80; iron (mg) 0.72, resp. 1.02 and sodium (mg) 65, resp.

The main goal of animal production is to ensure a consistent chemical composition of meat, from which its high nutritional value derives. However, in addition to the basic chemical composition, other parameters such as the content of minerals and biologically active substances have recently been monitored (AlYasiry, Kiczorowska and Samolińska, 2017). The final quality of meat products, as well as the quality of the large-scale meat production, is ensured by the appropriate composition of the poultry feed (Ciurescu et al., 2016) as well as by selected feeding method (Kiczorowska et al., 2015). Changes in the chemical composition of poultry meat are also related to the rations and feed nutrients assimilation. Nutrition and various supplements can lead to improved but also deteriorating of meat quality (Morales-Barrera et al., 2013; Dwiloka et al., 2015; Yogesh et al., 2015). Supplementation of chicken nutrition is nowadays aim of many researchers. Many plant products are being tested, such as probiotics, prebiotics, organic acids, enzymes, plant products and other antimicrobials applied via water or feed. Their aim is to improve chickens' digestion, health and in the end final products - meat and eggs (Trembecká et al., 2017; Pavelková et al., 2020).

The growth of the world's population is forcing scientists to look for alternative sources of feed for cereals, which are the main components of the human diet Each year, several researchers focus on the use of agricultural by-products and wastes produced in billions of tones (Xie et al., 2016). Nowadays, the use of plant-origin supplements in animal nutrition has become very popular. Because of this, researchers' attention concentrates towards natural additives application into animal diets due to their content of different functional components (Ramay 
and Yalçın, 2020). Eco-innovations in agriculture are based on the circular economy. The circular economy is an innovative approach that focuses on the "zero waste" economy, where new waste and raw materials are already generated from other waste and raw materials (Mirabella, Castellani and Sala, 2014). In addition, there has recently been a growing interest in obtaining various biologically active substances (polyphenols, flavonoids and simple phenolic substances) from these wastes and using them in animal nutrition for improving their health and performance (Liehr et al., 2017; Leskovec et al., 2018).

Antibiotics are commonly used not only for treatment but also for prevention of bacterial deceases in the industrial breeding of broiler chickens. Antibioticresistant bacterial strains as well as their residues in meat and various animal products have reduced the use of feed antibiotics (Zhang et al., 2016; Wang et al., 2017). The global strategy also leads to a reduction in the use of antibiotics and other medicines in livestock, and therefore various products rich in bioactive compounds with antimicrobial, antioxidant and anti-inflammatory properties are being sought. It is these natural feed additives that are promising alternatives to antibiotics (Niewold, 2014; Lillehoj et al., 2018).

The grapevine is one of the most economically important crops in the world Grapes are mainly used for wine production, but also for consumption and products as dried grapes and juices (Fortes and Pais, 2016). Grape pomace is a waste originating mainly from the production of wine, where the stems are removed separately, and the pomace is formed only by skins and grape seeds Among the known products that are produced from grape pomace are grape seed oil and grappa. Pomace from red grape varieties is used to obtain natural food colorings - anthocyanins (Schreiber, 2019). It is estimated that grape pomace makes up to $20 \%$ of the total weight of the grapes, therefore this is a considerable waste disposal problem for the wineries and other grape-processing industrie (Llobera and Cañellas, 2007). Due to their nutritional composition (various antioxidants, especially polyphenols), they should not be easily disposed of and should be further processed and used across the food sector (Theagarajan et al. 2019), for example in an animal nutrition (Aditya et al., 2018)

The effect of grape pomace enrichment in broiler chicken nutrition was demonstrated in recent experiments (Ebrahimzadeh et al., 2018; Haščík et al., 2020; Turcu et al., 2020). Among the older researches, we can mention that enrichment with source of antioxidants in form of GP at $30 \mathrm{~g} \cdot \mathrm{kg}^{-1}$ (Brenes et al. 2008) and 60 g. $\mathrm{kg}^{-1}$ (Goñi et al., 2007) led to lower lipid oxidation in chicken meat. Viveros et al. (2010) found higher amounts of beneficial bacteria in the broilers' intestines after application of GP. On the other side, dried RGP at levels ranging from 2.5 to $10 \mathrm{~g} . \mathrm{kg}^{-1}$ feed failed in extending the shelf life and the eating quality of the produced meat (Kasapidou et al., 2016)

The aim of the present study was to evaluate the chemical composition of Ross 308 broiler chickens' muscle (breasts and thighs) after addition of RGP (variety Alibernet) into their diet.

\section{MATERIAL AND METHODS}

\section{Animals and experimental design}

The experiment took place in the SUA, Nitra (Test poultry station, Kolínany) The methodology of fattening process was realized according to Hašč́k et al. (2020).
FMs were prepared according to Bulletin of MARD SR (2005) to meet nutritional needs of Ross 308 broiler chickens following the recommended reference levels. In the first stage $(1-21 \mathrm{~d})$, broilers were fed with HYD-0 starter FM following with grower HYD-02 from $22^{\text {nd }}$ day to the end of fattening in $42^{\text {nd }}$ day. The starter and grower FMs were did not contain any antibiotics and coccidiostatics and were prepared by Biofeed, Inc. (Kolárovo, Slovakia). The control group (C) received the basal diet without supplementation. The FM of experimental groups were enriched with RGP in amount $1 \% .100 \mathrm{~kg}^{-1}$ of FM (E1); $2 \% .100 \mathrm{~kg}^{-1}$ of FM (E2) and $3 \% .100 \mathrm{~kg}^{-1}$ of FM (E3). Composition of starter and grower FMs are designed according to study of Haščík et al. (2020).

\section{Characterization of grape pomace applied in experiment}

Used supplement (Alibernet RGP) was analyzed on the Department of Animal

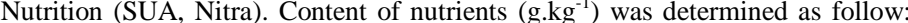
dry matter -383.50 , crude protein -112.80 , ether extract -105.91 , crude fiber 230.31 , ash -65.55 , nitrogen free extracts -485.74 , organic matter -949.56 , sugars -4.89 , acid detergent fiber -450.81 , neutral detergent fiber -525.46 , lignin -281.29 , celluloses -156.48 and hemicelluloses -91.82 .

\section{Slaughter and measurements}

At $42^{\text {nd }}$ day of age, 10 females and 10 males from each group were selected After weighing, they were slaughtered at the experimental slaughterhouse of the Department of Technology and Quality of Animal Products (SUA, Nitra) Slaughter was executed by conventional neck cut, with following bleeding, feathers removing and eviscerating.

Skinless breast (musculus pectoralis major) and thigh muscle (musculus biceps femoris) from each group were taken for evaluation of basic chemica composition (water, crude protein fat and cholesterol content in $\mathrm{g} .100 \mathrm{~g} \mathrm{~g}^{-1}$ ) performed with INFRATEC 1265 device (Germany)

\section{Statistical analysis}

Acquired data were processed with SAS software, Enterprise Guide 4.2 application (version 9.3, SAS Institute Inc., USA, 2008), using analysis of variance (ANOVA). Results were reported as mean \pm standard deviation Statistical significances between groups were calculated using the $t$-test and considered significant at $\mathrm{P} \leq 0.05$.

\section{RESULTS AND DISCUSSION}

The results of experiment with Ross 308 broiler chickens after addition of Alibernet RGP, which was aimed to analyze and evaluate chemical parameters, are presented as follows: the results of water content, crude protein, fat, and cholesterol content in breast and thigh muscle are given Table 1 and 2, respectively.

Table 1 Chemical composition of breast muscle of broiler chickens regarding sex (g.100 g $\left.\mathrm{g}^{-1}\right)$

\begin{tabular}{lcccccc}
\hline Parameter & sex & C & E1 & E2 & E3 & $p$-value \\
\hline Water content & Male & $70.56 \pm 0.95$ & $70.77 \pm 0.79$ & $70.77 \pm 1.01$ & $70.35 \pm 0.83$ & 0.425 \\
& Female & $70.83 \pm 0.78$ & $71.16 \pm 0.63$ & $70.72 \pm 0.75$ & $70.78 \pm 0.36$ \\
Crude protein & Male & $24.02 \pm 0.13$ & $23.88 \pm 0.22$ & $23.65 \pm 0.41$ & $24.27 \pm 0.29$ & 0.323 \\
& Female & $23.72 \pm 0.18$ & $23.63 \pm 0.21$ & $23.97 \pm 0.34$ & $23.75 \pm 0.47$ & 0.066 \\
Fat & Male & $0.90 \pm 0.24$ & $1.19 \pm 0.04$ & $1.32 \pm 0.42$ & $1.12 \pm 0.18$ & 0.128 \\
& Female & $1.03 \pm 0.25$ & $1.18 \pm 0.21$ & $1.22 \pm 0.21$ & $1.40 \pm 0.08$ \\
Cholesterol & Male & $0.040 \pm 0.004$ & $0.040 \pm 0.007$ & $0.041 \pm 0.002$ & $0.041 \pm 0.002$ \\
& Female & $0.041 \pm 0.006$ & $0.041 \pm 0.005$ & $0.044 \pm 0.006$ & $0.048 \pm 0.004$
\end{tabular}

Notes: mean \pm S.D. (standard deviation); $\mathrm{C}=$ control group; E1, E2, E3 = experimental groups; $\mathrm{a}, \mathrm{b}=$ means significant differences between groups $(\mathrm{P} \leq 0.05)$ determined with $t$-test.

Table 2 Chemical composition of thigh muscle of broiler chickens regarding sex $\left(\mathrm{g} .100 \mathrm{~g}^{-1}\right)$

\begin{tabular}{|c|c|c|c|c|c|c|}
\hline Parameter & sex & $\mathbf{C}$ & E1 & E2 & E3 & $p$-value \\
\hline \multirow[t]{2}{*}{ Water content } & Male & $71.26 \pm 0.51^{\mathrm{a}}$ & $70.65 \pm 0.31^{\mathrm{ac}}$ & $70.04 \pm 0.48^{\mathrm{bc}}$ & $69.51 \pm 0.77^{b}$ & 0.033 \\
\hline & Female & $70.44 \pm 0.46$ & $70.12 \pm 0.42$ & $69.58 \pm 0.60$ & $70.29 \pm 0.36$ & 0.323 \\
\hline \multirow[t]{2}{*}{ Crude protein } & Male & $21.78 \pm 0.18^{\mathrm{ab}}$ & $21.63 \pm 0.14^{b}$ & $21.59 \pm 0.18^{b}$ & $21.91 \pm 0.14^{\mathrm{a}}$ & 0.047 \\
\hline & Female & $21.80 \pm 0.11$ & $21.69 \pm 0.04$ & $21.75 \pm 0.28$ & $21.79 \pm 0.27$ & 0.100 \\
\hline \multirow[t]{2}{*}{ Fat } & Male & $2.51 \pm 0.24$ & $2.67 \pm 0.26$ & $2.67 \pm 0.49$ & $2.45 \pm 0.43$ & 0.323 \\
\hline & Female & $1.99 \pm 0.19$ & $2.31 \pm 0.20$ & $2.82 \pm 0.35$ & $2.83 \pm 0.26$ & 0.066 \\
\hline \multirow[t]{2}{*}{ Cholesterol } & Male & $0.061 \pm 0.002$ & $0.065 \pm 0.004$ & $0.065 \pm 0.005$ & $0.062 \pm 0.007$ & 0.124 \\
\hline & Female & $0.054 \pm 0.005$ & $0.060 \pm 0.001$ & $0.069 \pm 0.003$ & $0.064 \pm 0.004$ & 0.091 \\
\hline
\end{tabular}

Notes: mean \pm S.D. (standard deviation); $\mathrm{C}=$ control group; E1, E2, E3 = experimental groups; $\mathrm{a}, \mathrm{b}$, $\mathrm{c}=$ means significant differences

between groups $(\mathrm{P} \leq 0.05)$ determined with $t$-test. 


\section{Water content}

The highest water content in breast muscle was recorded in experimental groups E1 and E2 - 70.77 g. $100 \mathrm{~g}^{-1}$ in males, while in females it was E1 group 71.16 g. $100 \mathrm{~g}^{-1}$, but these differences between groups were minimal and not significant $(\mathrm{P} \geq 0.05)$. However, in thigh muscle we found significantly lower $(\mathrm{P} \leq 0.05)$ water content in experimental group E2 - 70.04 g.100 g $\mathrm{g}^{-1}$ and E3 - $69.51 \mathrm{~g}^{100 \mathrm{~g}^{-1}}$ compared to control group $-71.26 \mathrm{~g} .100 \mathrm{~g}^{-1}\left(\delta^{-}\right)$. In females we did not found significant differences $(\mathrm{P} \geq 0.05)$ between groups with the highest water content in control group -70.44 g. $100 \mathrm{~g}^{-1}$.

In comparison, significantly lower $(\mathrm{P} \leq 0.05)$ water content revealed Nardoia (2016) in broilers breast muscle after feed-addition of $4 \%$ grape skin $(74.38 \mathrm{~g} .100$ $\left.\mathrm{g}^{-1}\right)$ and $4 \%$ of grape pomace (74.61 g. $100 \mathrm{~g} \mathrm{~g}^{-1}$ ) compared to control group (75.35 g.100 $\left.\mathrm{g}^{-1}\right)$. Any significant differences $(\mathrm{P} \geq 0.05)$ were described after enrichment with grape pomace supplementation of $2.5 \%, 5 \%$ and $7 \%$ in study of Bennato et al. (2020) with water content ranging around $\varnothing 73.6 \mathrm{~g} .100 \mathrm{~g}^{-1}$. Neither Reyes et al. (2020) did not find significant differences $(\mathrm{P} \geq 0.05)$ (in breast, resp. thigh muscle) after $20 \%$ addition of white grape pomace $\left(73.3\right.$ and $74.0 \mathrm{~g} .100 \mathrm{gg}^{-1}$, respectively) and $20 \%$ addition of red grape pomace $\left(72.6\right.$, resp. $\left.73.3 \mathrm{~g} .100 \mathrm{~g}^{-1}\right)$ compared to control group (73.5 and 73.1 g. $100 \mathrm{~g} \mathrm{~g}^{-1}$, respectively). Nonsignifican differences were evaluated in study of Zajac et al. (2020) after application of camelina, flax and sunflower into broiler chickens' diet, with water content around $\varnothing 76.4 \mathrm{~g} .100 \mathrm{~g}^{-1}$ in breast muscle and $\varnothing 75.2 \mathrm{~g} .100 \mathrm{~g}^{-1}$ in thigh muscle Also Haščík et al. (2018b) did not find any significant differences in breast muscle water content $(\mathrm{P} \geq 0.05)$ after used supplementation, however confirmed significantly higher water content $(\mathrm{P} \leq 0.05)$ in thigh muscle in experimental group fed with addition of $1 \%$ humic acid and probiotic Lactobacillus fermentum $(73.41$ g. $100 \mathrm{~g} \mathrm{~g}^{-1}$ ) and in experimental group fed with addition of coccidiostaticum Diclazuril and Salinomycinum sodium in growth feed mixtures $\left(73.34 \mathrm{~g} .100 \mathrm{~g}^{-1}\right)$ compared to experimental group fed with $1 \%$ humic acid $\left(70.42 \mathrm{~g} .100 \mathrm{~g} \mathrm{~g}^{-1}\right)$ and control group (71.73 g.100 g $\mathrm{g}^{-1}$ ), what is in contrast with our results. Compared to us, higher water content $(\mathrm{P} \geq 0.05)$ was discovered in study of Gungor and Erener (2020) after addition of raw and fermented sour cherry kernel into broiler chickens' diet, ranging from $73.03 \%$ ( $1 \%$ fermented sour cherry kernel) to $74.39 \%$ (2\% raw sour cherry kernel) in breast muscle and from $75.62 \%$ (2\% fermented sour cherry kernel) to $77.23 \%$ (1\% raw sour cherry kernel) in thigh muscle. Either supplemental pine needles powder $(0.25,0.50,0.75$ and $1 \%)$ did not have any effect $(\mathrm{P} \geq 0.05)$ on broiler chickens' breast water content, ranging $\varnothing$ $73.53 \%$ (Ramay and Yalçın, 2020).

\section{Crude protein}

We did not discover any significant differences in breast muscle crude protein content; its content was similar in both males and females in all monitored

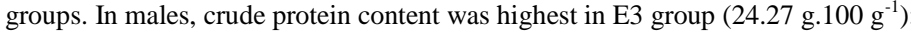
while in females it was in E2 group (23.97 g. $100 \mathrm{~g}^{-1}$ ). On the other side, in thigh muscle we found significantly highest crude protein content $(\mathrm{P} \leq 0.05)$ in males in experimental group E3 (21.91 g.100 g $\mathrm{g}^{-1}$ ) compared to experimental groups E1 $\left(21.63 \mathrm{~g} .100 \mathrm{~g}^{-1}\right)$ and E2 $\left(21.59 \mathrm{~g} .100 \mathrm{~g}^{-1}\right)$. However, in females these relativities were not confirmed $(\mathrm{P} \geq 0.05)$, with crude protein content ranging $\varnothing 21.75$ g.100 $\mathrm{g}^{-1}$.

Lower crude protein content was found by Nardoia (2016), who also did not find significant differences $(\mathrm{P} \geq 0.05)$ in its content in broilers breast muscle after feedaddition of $4 \%$ grape seeds $\left(21.86 \mathrm{~g} .100 \mathrm{~g}^{-1}\right), 4 \%$ grape skin $\left(22.46 \mathrm{~g} .100 \mathrm{~g}^{-1}\right)$ or $4 \%$ of grape pomace $\left(22.53\right.$ g. $\left.100 \mathrm{~g} \mathrm{~g}^{-1}\right)$ compared to control group $(22.32 \mathrm{~g} .100 \mathrm{~g}$ $\left.{ }^{1}\right)$. Any significant differences $(\mathrm{P} \geq 0.05)$ were evaluated after enrichment with grape pomace supplementation of $2.5 \%, 5 \%$ and $7 \%$ in study of Bennato et al. (2020) when crude protein ranged from 23.4 g. $100 \mathrm{~g}^{-1}$ (control group) to 24.3 g. $100 \mathrm{~g}^{-1}$ (7\% addition of grape pomace). Neither Reyes et al. (2020) did not find significant differences $(\mathrm{P} \geq 0.05)$ (in breast, resp. thigh muscle) after $20 \%$ addition of white grape pomace $\left(23.8\right.$, resp. $\left.18.3 \mathrm{~g} .100 \mathrm{~g}^{-1}\right)$ and $20 \%$ addition of red grape pomace $\left(23.2\right.$, resp. 18.9 g. $\left.100 \mathrm{~g}^{-1}\right)$ compared to control group (23.9, resp. 19.0 g.100 g $\left.\mathrm{g}^{-1}\right)$. Also, any significant differences $(\mathrm{P} \geq 0.05)$ were described after camelina, flax, and sunflower enrichment, when protein content ranged $\varnothing 20.9$ g.100 g $\mathrm{g}^{-1}$ in breast muscle and $\varnothing 18.1 \mathrm{~g} .100 \mathrm{~g}^{-1}$ in thigh muscle (Zajac et al. 2020). On the other hand, Haščík et al. (2018b) revealed the highest protein content $(\mathrm{P} \leq 0.05)$ in breast muscle without any supplementation in control group (23.42 g.100 g $\mathrm{g}^{-1}$ ) compared to supplementation with humic acid and probiotic (22.49 g.100 g $\mathrm{g}^{-1}$ ). In the case of thigh muscle was measured the lowest value of crude protein content 18.70 g. $100 \mathrm{~g}^{-1}$ in experimental group fed with addition of humic acid and probiotic Lactobacillus fermentum and the higher value in experimental group fed with addition growth FM with Salinomycinum sodium and coccidiostaticum (19.93 g.100 g $\mathrm{g}^{-1}$. Nonsignificant differences $(\mathrm{P} \geq 0.05)$ were discovered in study of Gungor and Erener (2020) after addition of raw and fermented sour cherry kernel into broiler chickens' diet, with the lowest $(22.77 \%$ - $2 \%$ raw sour cherry kernel) versus highest $(24.21 \%-4 \%$ raw sour cherry kernel) crude protein content in breast muscle and the lowest $(19.02 \%$ - $1 \%$ raw sour cherry kernel) versus the highest $20.24 \%$ ( $2 \%$ fermented sour cherry kernel) in thigh muscle. Either supplemental pine needles powder $(0.25,0.50,0.75$ and
$1 \%)$ did not have any significant effect $(\mathrm{P} \geq 0.05)$ on broiler chickens' breast crude protein content, ranging $\varnothing 24.10 \%$ (Ramay and Yalçın, 2020).

\section{Fat}

Grape seeds as a major part of grape pomace are a rich source of lipids, ranging between $14-17 \%$ (Gül et al., 2013; Mironeasa et al., 2016). This might be a reason why we found generally higher fat content $(\mathrm{P} \geq 0.05)$ in experimental groups in comparison with control group. The highest fat content in breas muscle was in experimental group E2 - $1.32 \mathrm{~g} .100 \mathrm{~g}^{-1}\left({ }^{\circledR}\right)$ and E3 - $1.40 \mathrm{~g} .100 \mathrm{~g}^{-1}$ (). In thigh muscle fat content was the highest in experimental groups E1 and

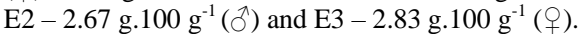

Also, Nardoia (2016) did not find significant differences $(\mathrm{P} \geq 0.05)$ in fat content in broilers breast muscle after feed-addition of $4 \%$ grape seeds $(1.97 \%)$, $4 \%$ grape skin $(1.59 \%)$ and $4 \%$ of grape pomace $(1.74 \%)$ compared to control group $(1.71 \%)$. Bennato et al. (2020) found similar reliance in increasing fat content after enrichment with grape pomace supplementation of $2.5 \%\left(1.16 \mathrm{~g} .100 \mathrm{~g}^{-1}\right)$, $5 \%\left(1.22 \mathrm{~g} .100 \mathrm{~g}^{-1}\right)$ and $7 \%\left(1.25 \mathrm{~g} .100 \mathrm{~g}^{-1}\right)$ as we did, however these differences were not significant $(\mathrm{P} \geq 0.05)$. On the other hand, Reyes et al. (2020) found significant differences in breast muscle after $20 \%$ addition of white grape pomace (1.6\%) and $20 \%$ addition of red grape pomace (2.8\%) compared to control group $(0.9 \%)$. In contrast with our results may be feed enrichment with camelina, flax and sunflower described by Zajac et al. (2020), who found significantly lower $(\mathrm{P} \leq 0.05)$ fat content (in g.100 $\left.\mathrm{g}^{-1}\right)$ in all experimental groups -1.07 (camelina), 1.04 (flax) and 1.08 (sunflower) compared to control group (1.34) in breas muscle and 5.10 (camelina), 5.06 (flax) and 4.61 (sunflower) compared to control group (7.50) in thigh muscle. Haščík et al. (2018b) found significantly lowest fat content after enrichment with $1 \%$ humic acid in breast muscle $\left(0.84 \mathrm{~g} .100 \mathrm{~g} \mathrm{~g}^{-1}\right)$ and in control group in thigh muscle $\left(7.15 \mathrm{~g} .100 \mathrm{~g}^{-1}\right)$. Any significant changes $(\mathrm{P} \geq 0.05)$ were also observed after dietary supplementation with raw and fermented sour cherry kernel $(1,2$ and $4 \%)$ in breast and thigh fat content (Gungor and Erener, 2020) or supplemental pine needles powder (0.25, 0.50, 0.75 and 1\%) in breast fat content (Ramay and Yalçın, 2020).

\section{Cholesterol}

Cholesterol content was not markedly affected $(\mathrm{P} \geq 0.05)$ by selected dietary supplementation. In breast muscle its content varied between $0.040-0.048 \mathrm{~g} .100$ $\mathrm{g}^{-1}$ in all observed groups $(\hat{\sigma},+)$ and slightly higher in thigh muscle $\varnothing 0.063$ g. $100 \mathrm{~g}^{-1}$ with the lowest concentrations in control group $-0.061 \mathrm{~g}^{\circ} 100 \mathrm{~g}^{-1}\left(\mathrm{O}^{\top}\right)$

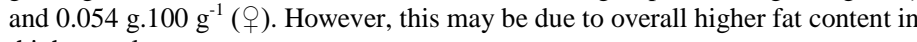
thigh muscle.

Our results are similar with results of Turcu et al. (2019), who observed that after addition of grape seed meal the cholesterol level in the fat from the breast meat samples was $8.13 \%$ lower $(\mathrm{P} \geq 0.05)$ in the experimental group (40.68

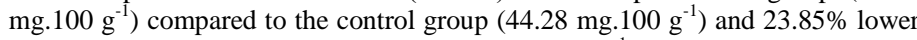
$(\mathrm{P} \leq 0.05)$ in the experimental group $\left(46.38 \mathrm{mg} .100 \mathrm{~g}^{-1}\right)$ compared to the control group (60.91 mg.100 g $\left.\mathrm{g}^{-1}\right)$ in thigh muscle. Hašćík et al. (2016) discovered higher $(\mathrm{P} \geq 0.05)$ cholesterol content in thigh muscle in experimental groups -113.08 mg.100 $\mathrm{g}^{-1}$ (probiotics addition), $118.68 \mathrm{mg} .100 \mathrm{~g}^{-1}$ (propolis addition) in comparison with control group $121.25 \mathrm{mg} .100 \mathrm{~g}^{-1}$. However similar results were described by Hašč́k et al. (2018b) who also did not find any differences in chicken breasts cholesterol content $(\mathrm{P} \geq 0.05)$, ranging from $0.033 \mathrm{~g} .100 \mathrm{~g}^{-1}$ (experimental group P1 with addition humic acids) to $0.039 \mathrm{~g} .100 \mathrm{~g}^{-1}$ (experimental group P2 with addition humic acids and probiotic). In thigh muscle, the cholesterol content was significantly lowest $(\mathrm{P} \leq 0.05)$ in control group -0.070 g. $100 \mathrm{~g}^{-1}$ compared to $0.086 \mathrm{~g} .100 \mathrm{~g}^{-1}$ in experimental groups $\mathrm{P} 1$ and $\mathrm{P} 2$. Cholesterol lowering in broiler meat (breasts and thighs) is important for human nutrition and health, in reducing the risks associated with cardiovascular diseases (Pavlović et al., 2018).

\section{CONCLUSION}

The results of our study have shown that the application of the red grape pomace in used concentrations did not markedly influence on the chemical composition of breast muscle. The results have shown that dietary supplementation with red grape pomace in chicken nutrition slightly improved the content of protein and slightly decreased the water content in the thigh muscle $(\mathrm{P} \leq 0.05)$ in males. However, selected parameters were not significantly affected $(P \geq 0.05)$ in females. Chosen dietary supplementation increased $(\mathrm{P} \geq 0.05)$ fat content in experimental groups $(\hat{O},+$ ) without significant increase $(\mathrm{P} \geq 0.05)$ of cholesterol content. The conclusion is that any feed supplement should not have a negative impact on the final quality of broiler chicken meat, but also on the health of the food consumer. From this point of view, red grape pomace as a voluminous agricultural waste seems to be a suitable candidate in broiler chicken's nutrition.

Acknowledgments: This publication was supported by the Operational program Integrated Infrastructure within the project: Demand-driven research for the sustainable and inovative food, Drive4SIFood 313011V336, cofinanced by the 
Euruopean Regional Development Fund, [VEGA] under grant [no. 1/0722/19] and [KEGA] [no. 027SPU-4/2019].

\section{REFERENCES}

Aditya, S., Ohh, S.-J., Ahammed, M., \& Lohakare, J. (2018). Supplementation of grape pomace (Vitis vinifera) in broiler diets and its effect on growth performance, apparent total tract digestibility of nutrients, blood profile, and meat $\begin{array}{llll}\text { quality. Animal } & \text { Nutrition, } & \text { 210-214 }\end{array}$ https://doi.org/10.1016/j.aninu.2018.01.004

Al-Yasiry, A.R.M., Kiczorowska, B. \& Samolińska, W. Effect of Boswellia serrata Resin Supplementation on Basic Chemical and Mineral Element Composition in the Muscles and Liver of Broiler Chickens. Biological Trace Element Research, 179, 294-303. https://doi.org/10.1007/s12011-017-0966-6 Bennato, F., Di Luca, A., Martino, C., Ianni, A., Marone, E., Grotta, L., Ramazzotti, S. \& Martino, G. (2020). Influence of Grape Pomace Intake on Nutritional Value, Lipid Oxidation and Volatile Profile of Poultry Meat. Foods, 9(4), 508. https://doi.org/10.3390/foods9040508

Bobko, M., Haščík, P., Bobková, A., Kročko, M., Tóth, T. (2017). Vplyv rôznych kŕmnych doplnkov na obsah tuku a oxidačnú stabilitu kuracieho mäsa. Český Těšín: 2 THETA. $112 \mathrm{p}$.

Brenes, A., Viveros, A., Goñi, I., Centeno, C., Sáyago-Ayerdy, S. G., Arija, I., \& Saura-Calixto, F. (2008). Effect of Grape Pomace Concentrate and Vitamin E on Digestibility of Polyphenols and Antioxidant Activity in Chickens. Poultry Science, 87(2), 307-316. https://doi.org/10.3382/ps.2007-00297

Cavani, C., Petracci, M., Trocino, A., \& Xiccato, G. (2009). Advances in research on poultry and rabbit meat quality. Italian Journal of Animal Science, 8(2), 741-750. https://doi.org/10.4081/ijas.2009.s2.741

Ciurescu, G.; Ropota, M.; Toncea, I.; Habeanu, M. Camelia (Camelina sativa L. Crantz Variety) oil and seeds as n-3 fatty acids rich products in broiler diets and its effects on performance, meat fatty acid composition, immune tissue weights, and plasma metabolic profile. Journal of Agricultural Science and Technology, 18, 315-326.

Čuboň, J., Haščík, P., Eliman, I. O. E., Garlík, J., Kačániová, M., \& Mohammed H. A. (2013). The influence of bee pollen on the meat chemical composition for broiler's Ross 308 muscles. Journal of Microbiology, Biotechnology and Food Sciences, 2(1), 1128-1137

Dwiloka, B., Setiadi, A., Imam Santoso, S., Suprijatna, E., \& Susanti, S. (2015) Effects of duck feed supplemented with invasive giant salvinia(Salvinia molesta) on duck meat characteristics. Turkish Journal of Veterinary and Animal Sciences, 39, 668-675. https://doi.org/10.3906/vet-1411-52

Ebrahimzadeh, S. K., Navidshad, B., Farhoomand, P., \& Mirzaei Aghjehgheshlagh, F. (2018). Effects of grape pomace and vitamin E on performance, antioxidant status, immune response, gut morphology and histopathological responses in broiler chickens. South African Journal of Animal Science, 48(2), 324. https://doi.org/10.4314/sajas.v48i2.13

FAO. 2020 Food Outlook - Biannual Report on Global Food Markets: June 2020 Food Outlook, 1. Rome. https://doi.org/10.4060/ca9509e

Farahat, M. H., Abdallah, F. M., Ali, H. A., \& Hernandez-Santana, A. (2016) Effect of dietary supplementation of grape seed extract on the growth performance, lipid profile, antioxidant status and immune response of broiler chickens. Animal, 11(5), 771-777. https://doi.org/10.1017/s1751731116002251

Fortes, A. M. \& Pais, M. S. 2016. Chapter 12 - Grape (Vitis species). Nutritional Composition of Fruit Cultivars. Academic Press: 257-286. https://doi.org/10.1016/B978-0-12-408117-8.00012-X

Goñi, I., Brenes, A., Centeno, C., Viveros, A., Saura-Calixto, F., Rebolé, A. Arija, A., \& Estevez, R. (2007). Effect of Dietary Grape Pomace and Vitamin E on Growth Performance, Nutrient Digestibility, and Susceptibility to Meat Lipid Oxidation in Chickens. Poultry Science, 86(3), 508-516. https://doi.org/10.1093/ps/86.3.508

Gungor, E., \& Erener, G. (2020). Effect of dietary raw and fermented sour cherry kernel (Prunus cerasus L.) on growth performance, carcass traits, and mea quality in broiler chickens. Poultry Science, 99(1), 301-309. https://doi.org/10.3382/ps/pez490

Gül, H., Acun, S., Sen, H., Nayir, N., \& Türk, S. (2013). Antioxidant activity, total phenolics and some chemical properties of Okuzgozu and Narince grape pomace and grape seed flours. Journal of Food Agriculture \& Environment, 11, 28-34.

Haščík, P., Arpášová, H., Pavelková, A., Bobko, M., Čuboň, J., \& Bučko, O. (2018b). Chemical composition of chicken meat after application of humic acid and probiotic Lactobacillus fermentum. Potravinarstvo Slovak Journal of Food Sciences, 12(1), 694-700. https://doi.org/10.5219/943

Haščík, P., Čech, M., Čuboň, J., Bobko, M., Arpášová, H., Pavelková, A., Kačániová, M., Tkáčová, J. \& Čeryová, N. (2020). Effect of grape pomace supplementation on meat performance of broiler chicken Ross 308. Journal of Microbiology, Biotechnology and Food Sciences, 10(1), 140-144. https://doi.org/10.15414/jmbfs.2020.10.1.140-144

Haščík, P., Trembecká, L., Bobko, M., Čuboň, J., Tóth, T., \& Ducková, V. (2018a). Effect of natural feed supplements on meat performance and meat quality of broiler chickens. Český Těšín: 2 THETA. 146 p.
Haščík, P., Trembecká, L., Bobko, M., Kačániová, M., Čuboň, J., Kunová, S., \& Bučko, O. (2016). Effect of diet supplemented with propolis extract and probiotic additives on performance, carcass characteristics and meat composition of broiler chickens. Potravinarstvo Slovak Journal of Food Sciences, 10(1), 223-231. https://doi.org/10.5219/581

Kasapidou, E., Soddidou, E.N., Zdragas, A., Papadaki, C., Vafeas, G., \& Mtlianga P. (2016). Effect of grape pomace supplementation on broiler meat quality characteristics. European Poultry Science, 80, 135-142.

https://doi.org/10.1399/eps.2016.135

Kiczorowska, B., Samolińska, W., Al-Yasiry A.R.M., Winiarska-Mieczan, A., \& Kwiecień, M. (2015). Nutritional value of poultry meat produced in conventional and organic systems. Problemy Higieny i Epidemiologii, 96(3), 598-602.

Leskovec, J., Levart, A., Žgur, S., Jordan, D., Pirman, T., Salobir, J., \& Rezar, V. (2018). Effects of Olive Leaf and Marigold Extracts on the Utilization of Nutrients and on Bone Mineralization using Two Different Oil Sources in Broilers. The Journal of Poultry Science, 55(1), 17-27. https://doi.org/10.2141/jpsa.0170059

Liehr, M., Mereu, A., Pastor, J. J., Quintela, J. C., Staats, S., Rimbach, G., \& Ipharraguerre, I. R. (2017). Olive oil bioactives protect pigs against experimentally-induced chronic inflammation independently of alterations in gut

$\begin{array}{lcc}\text { microbiota. } & \text { PLOS } & \text { ONE, } \\ \text { https://doi.org/10.1371/journal.pone.0174239 }\end{array}$

Lillehoj, H., Liu, Y., Calsamiglia, S., Fernandez-Miyakawa, M. E., Chi, F., Cravens, R. L., Oh, S. \& Gay, C. G. (2018). Phytochemicals as antibiotic alternatives to promote growth and enhance host health. Veterinary Research, 49(1). https://doi.org/10.1186/s13567-018-0562-6

Llobera, A., \& Cañellas, J. (2007). Dietary fibre content and antioxidant activity of Manto Negro red grape (Vitis vinifera): pomace and stem. Food Chemistry, 101(2), 659-666. https://doi.org/10.1016/j.foodchem.2006.02.025

Mirabella, N., Castellani, V., \& Sala, S. (2014). Current options for the valorization of food manufacturing waste: a review. Journal of Cleaner Production, 65, 28-41. https://doi.org/10.1016/j.jclepro.2013.10.051

Mironeasa, S., Codină, G. G., \& Mironeasa, C. (2015). Optimization of WheatGrape Seed Composite Flour to Improve Alpha-Amylase Activity and Dough Rheological Behavior. International Journal of Food Properties, 19(4), 859-872 https://doi.org/10.1080/10942912.2015.1045516

Morales-Barrera, J. E., Gonzalez-Alcorta, M. J., Castillo-Dominguez, R. M. Prado-Rebolledo, O. F., Hernandez-Velasco, X., Menconi, A., Tellez, G., Hargis, B. M. \& Carrillo-Dominguez, S. (2013). Fatty Acid Deposition on Broiler Mea in Chickens Supplemented with Tuna Oil. Food and Nutrition Sciences, 04(09), 16-20. https://doi.org/10.4236/fns.2013.49a1003

Nardoia, M. (2016). Effect of dietary polyphenol-rich grape byproducts on growth performance, some physiological parameters, meat and meat products quality in chickens (Doctoral dissertation). Retrieved from https://digital.csic.es/bitstream/10261/170939/1/TesiNardoia.pdf

Niewold, T. A. (2014). Why anti-inflammatory compounds are the solution for the problem with in feed antibiotics. Quality Assurance and Safety of Crops \& Foods, 6(2), 119-122. https://doi.org/10.3920/qas2012.0234

Pavelková, A., Hašč́k, P., Kalafová, A., Capcarová, M., Čuboň, J., Bučko, O. Kačániová, M., Hanusová, E., Tkáčová, J., \& Bobko, M. (2020). Chemical composition of muscle after bee bread application in the nutrition of japanese quails. Journal Of Microbiology, Biotechnology and Food Sciences, 9 (4), 831835. https://doi.org/10.15414/jmbfs.2020.9.4.831-835

Pavlović, J., Greenland, P., Deckers, J. W., Kavousi, M., Hofman, A., Ikram, M A., Franco, O. H. \& Leening, M. J. (2017). Assessing gaps in cholesterol treatment guidelines for primary prevention of cardiovascular disease based on available randomised clinical trial evidence: The Rotterdam Study. European Journal of Preventive Cardiology, 25(4), 420-431. https://doi.org/10.1177/2047487317743352

Pereira, P. M. de C. C., \& Vicente, A. F. dos R. B. (2013). Meat nutritiona composition and nutritive role in the human diet. Meat Science, 93(3), 586-592. https://doi.org/10.1016/i.meatsci.2012.09.018

Petracci, M., Bianchi, M., Mudalal, S., \& Cavani, C. (2013). Functional ingredients for poultry meat products. Trends in Food Science \& Technology, 33(1), 27-39. https://doi.org/10.1016/i.tifs.2013.06.004

Ramay, M. S., \& Yalçın, S. (2020). Effects of supplemental pine needles powder (Pinus brutia) on growth performance, breast meat composition, and antioxidan status in broilers fed linseed oil-based diets. Poultry Science, 99(1), 479-486 https://doi.org/10.3382/ps/pez542

Raza, A., Bashir, S., \& Tabassum, R. (2019). An update on carbohydrates: growth performance and intestinal health of poultry. Heliyon, 5(4), e01437. https://doi.org/10.1016/j.heliyon.2019.e01437

Reyes, P., Urquiaga, I., Echeverría, G., Durán, E., Morales, M. S., \& Valenzuela, C. (2020). Wine grape pomace flour in broiler diets effects growth and some meat characteristics. Animal Production Science, 60(9), 1210. https://doi.org/10.1071/an19385

Schieber, A. (2019). By-Products of Plant Food Processing as a Source of Valuable Compounds. Reference Module in Food Science. https://doi.org/10.1016/b978-0-08-100596-5.21346-2 
Shaltout, F. (2019). Poultry meat. Scholarly Journal of Food and Nutrition Editorial, 2(2), 209-210. https://doi.org/10.32474/SJFN.2019.02.000134

Theagarajan, R., Malur Narayanaswamy, L., Dutta, S., Moses, J. A., \& Chinnaswamy, A. (2019). Valorization of grape pomace (cv. Muscat) for development of functional cookies. International Journal of Food Science \& Technology, 54(4), 1299-1305. https://doi.org/10.1111/ijfs.14119

Trembecká, L., Haščík, P., Čuboň, J., Bobko, M., Cviková, P., \& Hleba, L. (2017). Chemical and sensory characteristics of chicken breast meat after dietary supplementation with probiotic given in combination with bee pollen and propolis. Journal of Microbiology, Biotechnology and Food Sciences, 7(3), 275280. https://doi.org/10.15414/jmbfs.2017/18.7.3.275-280

Turcu, R. P., Panaite, T. D., Untea, A. E., Soica, C., Iuga, M., \& Mironeasa, S. (2020). Effects of Supplementing Grape Pomace to Broilers Fed Polyunsaturated Fatty Acids Enriched Diets on Meat Quality. Animals, 10(6), 947 https://doi.org/10.3390/ani10060947

Turcu, R., Olteanu, M., Criste, R., Panaite, T., Ropotă, M., Vlaicu, P., \& Drăgotoiu, D. (2019). Grapeseed Meal Used as Natural Antioxidant in High Fatty Acid Diets for Hubbard Broilers. Brazilian Journal of Poultry Science, 21(2). https://doi.org/10.1590/1806-9061-2018-0886

Viveros, A., Chamorro, S., Pizarro, M., Arija, I., Centeno, C., \& Brenes, A. (2011). Effects of dietary polyphenol-rich grape products on intestinal microflora and gut morphology in broiler chicks. Poultry Science, 90(3), 566-578. https://doi.org/10.3382/ps.2010-00889

Wang, S., Peng, Q., Jia, H. M., Zeng, X. F., Zhu, J. L., Hou, C. L., Liu, X. T., Yang, F. J. \& Qiao, S. Y. (2017). Prevention of Escherichia coli infection in broiler chickens with Lactobacillus plantarum B1. Poultry Science, 96(8), 25762586. https://doi.org/10.3382/ps/pex061

Williams, P. (2007). Nutritional composition of red meat. Nutrition \& Dietetics, 64(4), 113-119. https://doi.org/10.1111/j.1747-0080.2007.00197.x

Xie, P. J., Huang, L. X., Zhang, C. H., \& Zhang, Y.L. (2016). Nutrient assessment of olive leaf residues processed by solid-state fermentation as an innovative feedstuff additive. Journal of Applied Microbiology, 121(1), 28-40. https://doi.org/10.1111/jam.13131

Yogesh, K., Langoo, B. A., Sharma, S. K., \& Yadav, D. N. (2013). Technological, physico-chemical and sensory properties of raw and cooked meat batter incorporated with various levels of cold milled flaxseed powder. Journal of Food Science and Technology, 52(3), 1610-1617. https://doi.org/10.1007/s13197-013-1185-6

Zając, M., Kiczorowska, B., Samolińska, W., \& Klebaniuk, R. (2020). Inclusion of Camelina, Flax, and Sunflower Seeds in the Diets for Broiler Chickens: Apparent Digestibility of Nutrients, Growth Performance, Health Status, and Carcass and Meat Quality Traits. Animals, 10(2), 321. https://doi.org/10.3390/ani10020321

Zhang, L., Zhang, L., Zhan, X., Zeng, X., Zhou, L., Cao, G., Chen, A. \& Yang, C. (2016). Effects of dietary supplementation of probiotic, Clostridium butyricum, on growth performance, immune response, intestinal barrier function, and digestive enzyme activity in broiler chickens challenged with Escherichia coli K88. Journal of Animal Science and Biotechnology, 7(1) https://doi.org/10.1186/s40104-016-0061-4 